\title{
RESULTS OF THE 67-TH SESSION OF THE UNITED NATIONS SCIENTIFIC COMMITTEE ON THE EFFECTS OF THE ATOMIC RADIATION (UNSCEAR)
}

Akleyev AV ${ }^{1,2}$, Azizova TV³ , Ivanov VK ${ }^{4}$, Karpikova LA ${ }^{5}$, Kiselev SM ${ }^{6}$, Melikhova EM ${ }^{7}$, Romanov SA ${ }^{3}$, Fesenko SV ${ }^{8}$, Shinkarev SM ${ }^{6}$

${ }^{1}$ Urals Research Center for Radiation Medicine of the Federal Medical and Biological Agency of Russia, Chelyabinsk, Russia

${ }^{2}$ Chelyabinsk State University, Chelyabinsk, Russia

${ }^{3}$ Southern Urals Biophysics Institute of the Federal Medical and Biological Agency of Russia, Ozyorsk, Chelyabinsk Oblast, Russia

${ }^{4}$ A. Tsyb Medical Radiological Research Center — branch of the National Medical Research Radiological Center of the Ministry of Health of the Russian Federation, Obninsk, Russia

${ }^{5}$ Federal Medical and Biological Agency, Moscow, Russia

${ }^{6}$ A. Burnasyan Federal Medical Biophysical Center of the FMBA of Russia, Moscow, Russia

${ }^{7}$ Nuclear Safety Institute of the Russian Academy of Sciences, Moscow, Russia

${ }^{8}$ Russian Institute of Radiology and Agroecology, Obninsk, Russia

The 67-th Session of the United Nations Scientific Committee on the Effects of the Atomic Radiation (UNSCEAR) took place in the form of videoconferences during 2-6 November 2020. Within the framework of the meetings of the Working group and subgroups the documents of the following projects were discussed: R.741 «Evaluation of medical exposure to ionizing radiation»; R.742 «Levels and effects of radiation exposure due to the accident at the Fukushima Daiichi nuclear power station: implications of information published since the UNSCEAR 2013 report»; R.743 «Biological mechanisms relevant for the inference of cancer risks from lowdose and low dose rate radiation»; R.744 «Evaluation of occupational exposure to ionizing radiation»; R.745 «Second primary cancer after radiotherapy»; R.746 «Epidemiological studies of radiation and cancer»; R.747 «Evaluation of public exposures to ionizing radiation from natural and man-made sources»; Project 67/7 «Implementation of the Committee's strategy to improve collection, analysis and dissemination of data on radiation exposure». The Committee also discussed the future research program (2020-2024); report to the UN General Assembly; public outreach activity including the strategy for the period $2020-2024$.

Keywords: $67^{\text {th }}$ UNSCEAR Session, low doses, biological effects, epidemiology, medical exposure, occupational exposure

Acknowledgement: the authors acknowledge the members of the Russian delegation: S. G. Mikheenko, R. M. Takhouov and V. Yu. Usoltsev for participating in the $67^{\text {th }}$ UNSCEAR Session, and also the URCRM employees: N. S. Kotova and A. Yu. Garbuzova for their assistance in preparation to the UNSCEAR Session.

Author contribution: all the authors equally contributed to the preparation of the manuscript.

$\triangle$ Correspondence should be addressed: Alexander V. Akleyev

Vorovsky, 68 A, Chelyabinsk, 454141; akleyev@urcrm.ru

Received: 08.12.2020 Accepted: 22.12.2020 Published online: 30.01.2021

DOI: $10.47183 /$ mes.2021.001

\section{ИТОГИ 67-Й СЕССИИ НАУЧНОГО КОМИТЕТА ПО ДЕЙСТВИЮ АТОМНОЙ РАДИАЦИИ ООН}

А. В. Аклеев ${ }^{1,2}$, Т. В. Азизова ${ }^{3}$ В. К. Иванов ${ }^{4}$, Л. А. Карпикова ${ }^{5}$, С. М. Киселев ${ }^{6}$, Е. М. Мелихова С. А. Романов $^{3}$, С. В. Фесенко C. М. Шинкарев 6

${ }^{1}$ Уральский научно-практический центр радиационной медицины Федерального медико-биологического агентства, Челябинск, Россия

2 Челябинский государственный университет, Челябинск, Россия

${ }^{3}$ Южно-Уральский институт биофизики Федерального медико-биологического агентства, Озерск, Челябинская область, Россия

${ }^{4}$ Медицинский радиологический научный центр имени А. Ф. Цыба - филиал Национального медицинского исследовательского радиологического центра, Обнинск, Россия

${ }^{5}$ Федеральное медико-биологическое агентство, Москва, Россия

${ }^{6}$ Федеральный медицинский биофизический центр имени А. И. Бурназяна Федерального медико-биологического агентства, Москва, Россия

${ }^{7}$ Институт проблем безопасного развития атомной энергетики, Москва, Россия

${ }^{8}$ Всероссийский научно-исследовательский институт радиологии и агроэкологии, Обнинск, Россия

В период со 2 по 6 ноября 2020 г. в формате видеоконференции прошла 67-я сессии Научного комитета по действию атомной радиации ООН (НКДАР OOH). В рамках совещаний Рабочей группы и подгрупп состоялось обсуждение документов по ряду проектов: R.741 «Оценка облучения пациентов от медицинских источников ионизирующего излучения»; R.742 «Уровни и эффекты радиационного облучения, обусловленного аварией на атомной станции «Фукусима-1»: последствия информации, опубликованной после выхода отчета НКДАР ООН 2013 г.»; R.743 «Биологические механизмы, влияющие на прогнозируемые риски рака при воздействии радиации в малых дозах и с низкой мощностью дозы»; R.744 «Оценка облучения персонала от источников ионизирующего излучения»; R.745 «Вторичные раки после радиотерапии»; R.746 «Эпидемиологические исследования радиации и рака»; R.747 «Облучение населения от естественных и искусственных источников»; проект 67/7 «Реализация стратегии Комитета по совершенствованию сбора, анализа и распространения данных по радиационному облучению». Комитет также обсудил будущую программу исследований (2020-2024); отчет Генеральной Ассамблее ООН; информационную и просветительскую деятельность НКДАР ООН, вКлючая стратегию на период $2020-2024$ гг.

Ключевые слова: 67-я сессия НКДАР ООН, малые дозы, биологические эффекты, эпидемиология, медицинское облучение, профессиональное облучение

Благодарности: авторы благодарят членов российской делегации С. Г. Михеенко, Р. М. Тахаоува и В. Ю. Усольцева за участие в 67-й сессии НКДАР ООН, а также сотрудников ФГБУН УНПЦ РМ ФМБА России Н. С. Котову и А. Ю. Гарбузову за помощь в подготовке к сессии НКДАР ООН.

Вклад авторов: вклад каждого автора в подготовку статьи равнозначный.

$\triangle$ Для корреспонденции: Александр Васильевич Аклеев ул. Воровского, д. 68 А, г. Челябинск, 454141; akleyev@urcrm.ru

Статья получена: 08.12.2020 Статья принята к печати: 22.12.2020 Опубликована онлайн: 30.01.2021

DOI: 10.47183/mes.2021.001 
The $67^{\text {th }}$ session of UNSCEAR took place from 2 to 6 November 2020, attended by more than 150 experts from 25 UNSCEAR Member-States (the Russian Federation, Argentine, Australia, Belarus, Belgium, Brazil, the UK, Germany, Egypt, India, Indonesia, Spain, Canada, China, the Republic of Korea, Pakistan, Peru, Poland, Slovakia, the USA, Ukraine, Finland, France, Sweden, and Japan), 4 observer-countries (Algeria, the Islamic Republic of Iran, Norway, and the United Arab Emirates) and also representatives of 8 international organizations:

- United Nations Environmental Programme (UNEP);

- International Atomic Energy Agency (IAEA);

- International Labour Organization (ILO);

- International Agency for Research on Cancer (IARC);

- World Health Organization (WHO);

- European Commission (EC);

- Food and Agriculture Organization (FAO);

- International Commission on Radiation Units and Measurements (ICRU).

The Session took place as an online meeting. The Russian delegation included 11 experts: A. V. Akleyev (the RF representative in the UNSCEAR, URCRM of the FMBA of Russia), T. V. Azizova (deputy RF representative in the UNSCEAR, SUBI of the FMBA of Russia) and S. A. Romanov (SUBI of the FMBA of Russia), V. K. Ivanov (A.Tsyb MRRC NMRRC branch of the FMBA of Russia), S. M. Kiselev and S. M. Shinkarev (SRC-FMBC of the FMBA of Russia), E. M. Melikhova (the Nuclear Safety Institute of the Russian Academy of Sciences), S. G. Mikheenko and V. Yu. Usoltsev (Rosatom), R. M. Takhauov (SBRC of the FMBA of Russia) and S. V. Fesenko (RIRA of the Ministry of Science and Higher Education of the Russian Federation).

Gillian Hirth (Australia) was Chair, Anna Friedl (Germany), Jing Chen (Canada) and Jin Kyung Lee (Republic of Korea) were Vice-Chairs, and Anssi Auvinen (Finland) was Rapporteur for the $67^{\text {th }}$ UNSCEAR Session. Borislava Batandjieva-Metcalf was UNSCEAR Secretary.

Within the framework of the $67^{\text {th }}$ UNSCEAR Session final scientific documents, progress reports, future programme of work of the Committee for 2020-2024, and Report to the UN General Assembly have been reviewed and discussed.

The Committee deliberated the following scientific documents which are to be finalized in 2020:

- R.741 «Evaluation of medical exposure to ionizing radiation»;

- R.742 «Levels and effects of radiation exposure due to the accident at the Fukushima Daiichi nuclear power station: implications of information published since the UNSCEAR 2013 report»;

- R.743 «Biological mechanisms relevant for the inference of cancer risks from low-dose and low dose rate radiation»;

- R.744 «Evaluation of occupational exposure to ionizing radiation»;

The Committee also reviewed the current status of the following reports:

- R.745 «Second primary cancer after radiotherapy»;

- R.746 «Epidemiological studies of radiation and cancer»;

- R747 «Evaluation of public exposure to ionizing radiation from natural and man-made sources»;

- Project 67/7 «Implementation of the Committee's strategy to improve collection, analysis and dissemination of data on radiation exposure».

Besides, public outreach activity of the Committee including the strategy for the period 2020-2024, and new projects which are planned to begin in 2021-2024 were also discussed.

Preparation for the session was carried out in two stages. At the first stage (13, 14 and 16 July, 2020), delegates of the
UNSCEAR State members deliberated the following documents online: R.741 «Evaluation of medical exposure to ionizing radiation»; R.742 «Levels and effects of radiation exposure due to the accident at the Fukushima Daiichi nuclear power station: implications of information published since the UNSCEAR 2013 report»; R.743 "Biological mechanisms relevant for the inference of cancer risks from low-dose and low dose rate radiation»; and R.744 «Evaluation of occupational exposure to ionizing radiation». After discussion, the Working Groups finalized the documents and introduced their updated versions during the $67^{\text {th }}$ Session.

The RF delegation took an active part in the preparation of the scientific documents, progress reports and future programme of work sending their comments and suggestions on the topics discussed before the $67^{\text {th }}$ Session. The members of the Russian delegation also participated in the discussion of the session materials during the $67^{\text {th }}$ UNSCEAR Session. In general, consideration and discussion of the scientific documents, progress reports and future programme of work went productively with an active engagement of all UNSCEAR Member-states.

Results of the discussion of the scientific documents Document R.741 «Evaluation of medical exposure to ionizing radiation»

The document «Evaluation of medical exposure to ionizing radiation" was approved for publication at the $67^{\text {th }}$ UNSCEAR Session. Compared with the previous publication, the current report tested a new approach to data stratification of global assessment of medical exposure of population. Previously, all countries were stratified into four categories according to the number of physicians per 1,000 people and for each, average frequency and mean dose were calculated for each type of procedure according to the available data. Then the average values in this category were extrapolated to the whole of the country. This approach is applicable provided that the world's population is more or less evenly distributed across all categories. However, over the past 10 years, there has been a major demographic shift in the world and this condition is no longer met. Therefore, an alternative approach has been used. It is based on the World Bank (WB) classification. Countries are divided according to the level of gross national income per caput into four groups: low, lower middle, upper middle and high. Over the past decade, these groups included 9\%, 39\%, $36 \%$ and $16 \%$ of the world's population, respectively. Since $\mathrm{WHO}$ also uses the WB classification, it becomes possible to compare data on medical exposure with other indicators of public health services collected by $\mathrm{WHO}$. An important feature of the methodological part of the prepared document is the development of a methodology for assessing the uncertainty of the data presented. The document presents errors (standard deviations) for global indicators of frequencies of different examinations and collective effective dose.

The Committee reviewed the results of the assessment of medical exposure in the light of its previous UNSCEAR 2008 report and made the following conclusions. Medical exposure of patients in quantitative terms remains the most significant source of radiation exposure of the population. The annual collective effective dose to the world population is 4.2 million man Sv, the annual per caput effective dose is $0.58 \mathrm{mSv}$. In general, the population exposure data are comparable to the results from the UNSCEAR 2008 document $(0.65 \mathrm{mSv})$ taking into account the uncertainty which is about $30 \%$. When analyzing UNSCEAR documents since 1988, there is 
a tendency to an increase of annual collective effective doses due to sources of medical exposure (0.37 mSv in 1988). As expected, the greatest contribution to a collective dose is made by computed tomography (CT) (62\%) with a 10\%-contribution to the structure of medical diagnostic studies associated with patient exposure. The second place, taking into account the dominant number (63\%) in the structure of medical diagnostics, is taken by X-ray and radiological procedures; their contribution to the collective dose is $23 \%$. Interventional radiology accounts for only $0.6 \%$ of all procedures, but it accounts for $8 \%$ of the total collective dose. Diagnostic nuclear medicine takes $1 \%$ of all procedures and $7 \%$ of the total collective dose. The contribution of $\mathrm{CT}$ to the total collective effective dose increased from 37 to $62 \%$, the share of interventional radiological procedures in the structure of the collective dose increased 8 times if compared to the estimates of 2008. At the same time, the contribution of research related to the application of nuclear medicine increased by only 1.4 times, remaining a minor component in the structure of medical diagnostics and treatment (1\%).

Despite the fact that the Committee did not take into account the contribution to the collective dose from therapeutic procedures, the intensity of their use in medical practice has sharply increased. The number of radionuclide therapy procedures increased by $60 \%$, radiation therapy - by $22 \%$ compared to the data of the previous UNSCEAR report.

It should be emphasized that medical exposure of the population is clearly correlated with the level of well-being of countries. Thus, in countries with high per capita income, the number of diagnostic procedures is 18 times higher than in low-income countries: the former account for about $70 \%$ of all medical radiological studies and $75 \%$ of the collective dose. This is reflected in the indicators of the annual dose and the collective dose to the population of the country as a whole (13 and 22 times higher, respectively).

To obtain assessments, the Committee for the first time used a system for collecting information in the form of questionnaires on medical exposure, which were sent to the participating countries for filling in and submitting national data to the UNSCEAR. This system allowed a significant increase in the amount of data for making estimates, but the uncertainty of the results also increased significantly. This is due to the inability of countries to provide the full amount of data requested, for example, on gender and age distributions of patients and on measured dose characteristics due to the lack of centralized data collection systems in most countries. Therefore, the key data sources in the preparation of the report were the results of the analysis of scientific literature, as well as the $\mathrm{WHO}$ resource base. Representatives of different countries, including Russia, proposed to optimize the questionnaire, focusing on the structure of radiation diagnostics and dosimetric parameters for calculating effective doses, and using dose coefficients for basic X-ray and radionuclide studies. An important result of the activities carried out by the Committee on data collection in the field of medical exposure was the understanding of the need to improve the existing data collection system in Russia, which is currently based on No.3-DOZ statistical reporting form (a form of Federal State Statistical Observation used by Rospotrebnadzor to collect information on exposure doses of patients during medical X-ray and radiological studies in order to protect the well-being of citizens of the Russian Federation) and form No. 30 of the Ministry of Health of Russia (Federal Statistical Observation form № 30 "Information about a medical organization"). The existing domestic statistical forms can be updated taking into account the presented methodology of data collection within the UNSCEAR project, which will significantly increase the reliability and volume of information provided, including for internal use.

As for the scientific aspect of the issue of discussing the exposure doses of the population from medical radiation sources, it is necessary to emphasize the importance of the discussion about the correctness of using the concepts of "effective dose" and "collective effective dose" in the analysis of medical exposure. Taking into account the irregularity of the exposure of patients during diagnostic procedures, it is advisable to use the absorbed dose in the organ. This issue is especially acute in the field of nuclear medicine. It is pointed out that when considering the issues of medical exposure, special attention should be paid to the assessment of individual rather than collective exposure doses. The position of the Committee on this issue is that the report does not aim at assessing the risks from medical exposure, but solves the problem of identifying trends in medical exposure of the population and comparing different types of radiation exposure procedures. It is recommended to emphasize in the text of the document that the estimate of the collective effective dose should not be used to assess the risk of medical exposure in epidemiological studies.

In conclusion, a few words should be said about the new methodology for assessing uncertainties. It is clear that this innovation is of fundamental importance, since we are talking about the correct accounting of statistical errors and the statistical significance of the identified global trends. The methodology presented in the document is the first step on this path. Therefore, it is not surprising that the final estimates of the uncertainties of global indicators in some cases look overly optimistic, if we take into account the quantity and quality of the initial data, the accuracy of modelling and some other points. The new methodology needs to be improved, and it should be done in parallel with the improvement of the initial data collection system. However, the discussion showed that experts working on the topic of medical exposure still consider the estimates of uncertainties as irrelevant information, which is clearly discordant with the Committee's approach to the use of statistical errors in medical records, for example, in radiation epidemiological studies. This situation will require correction in the very near future.

Document R.742 «Levels and effects of radiation exposure due to the accident at the Fukushima Daiichi nuclear power station: implications of information published since the UNSCEAR 2013 report»

The structure of the document follows the structure of the UNCEAR 2013 report. The new document contains seven thematic sections in addition to the introduction and conclusion:

- Releases of radionuclides to the atmosphere, their dispersion and deposition.

- Releases to the marine environment, their dispersion and deposition.

- Transfer in terrestrial and freshwater environments.

- Exposure of members of the public.

- Exposure of workers.

- Health implications for the public and workers.

- Exposures and effects for non-human biota.

The document confirms the main conclusion made in the UNSCEAR 2013 report that the radiation doses to the public and workers and, accordingly, the radiation risks were very low. It is expected that the health effects of radiation exposure will not be discernible against the background of spontaneous diseases in the population. At the same time, a number of changes were made to the text of the document R.742 in 
comparison with the UNSCEAR 2013 report, including clarifications on the assessment of exposure doses to the population.

The latest estimates of the total release of radioactive substances into the environment as a result of the accident, taking into account the analysis of all currently available data, have not fundamentally changed and do not contradict the previously published estimates. According to recent studies, ${ }^{131} \mathrm{I}$ and ${ }^{137} \mathrm{Cs}$ releases (two of the most significant radionuclides from the perspectives of population and biota exposure) are estimated to be $120 \mathrm{PBq}$ and $10 \mathrm{PBq}$, respectively. And it is considered that about $80 \%$ of the total release was dispersed over, and deposited on to, the Pacific Ocean.

It should be noted that during the preparation of the UNSCEAR 2013 report, the group of specialists preparing the report was tasked to make realistic assessments of the levels of exposure of workers, public and biota. However, very limited information on the results of measurements of the radionuclide content in environmental media, food, human body after the accident did not enable in the previous report to fully rely on objective measurement data when calculating radiation doses. The assumptions used turned out to be conservative and led to overestimation of doses. In this document, the most significant changes in models, methods and data that influenced the calculation results were related to the following aspects.

- A more realistic description of the dynamics of the release of radioactive material, their dispersion and surface deposition. At the same time, a large number of measurement results of the radionuclide content in environmental objects accumulated over the past years were used.

- An improved empirical model to estimate doses of external exposure of the population from radionuclide deposits was developed and validated by actual data. The model is based on long-term measurements of dose rate on the ground with different landscape and soil types typical of Japan.

- A special biokinetic model was developed specific to the Japanese population, taking into account the high content of stable iodine in the traditional daily diet of the Japanese. This model made it possible to more realistically estimate the exposure doses to the thyroid in the population from inhaled and ingested radioiodine. Within the framework of this model, for the same intake of radioiodine, the thyroid exposure doses are reduced by about two times

- When assessing the exposure doses to the population the numerical values of the parameters were corrected in the calculation models, taking into account the real picture of both the conditions of external exposure and the pathways of radionuclide intakes into the body when assessing internal exposure doses. For example, it was taken into account that the concentration of radionuclides inside dwellings was reduced by about two times compared to their concentration outside buildings, which led to a twofold decrease in internal exposure doses through the inhalation pathways.

- Instead of the previously used conservative parameters of the population's dietary intake of radionuclides, the new document adopted a more realistic approach based on the actual composition of the foodstuffs of the residents of the contaminated area in the months immediately following the accident. According to refined calculations, internal exposure doses of the population from ingestion declined by about 10 times.

The refinements introduced into the computational models led to a decrease in the average effective doses of the population for municipalities and prefectures by several tens of percent, and in terms of thyroid doses - by about two times. It is important to emphasize that the structure of revised thyroid doses in the population has changed. The contribution from the intake by radioiodine inhalation turned out to be more significant compared to the dietary intake after the Fukushima accident, which differs significantly from the picture of the formation of thyroid doses in the population after the Chernobyl accident, where the dominant pathway of radioiodine intake was the consumption of contaminated fresh cow milk by the residents from pasture grazed cows.

For the population of municipalities that was evacuated in the first days after the accident, the mean effective doses to 1 -year-old infants in the first year after the accident were in the range of $0.2-8.0 \mathrm{mSv}$, and the average absorbed thyroid doses were in the range of 2.0-30.0 mGy. Mean exposure doses to adults were $70 \%$ lower than to 1-year-old infants in relation to the effective dose and $50 \%$ in relation to the absorbed thyroid dose. For municipalities in Fukushima Prefecture that were not evacuated in the first days after the accident, the estimated mean effective doses to 1-year-old infants in the first year were in the range of about $0.1 \mathrm{mSv}-5 \mathrm{mSv}$, and the mean absorbed thyroid doses were in the range of 1.0-20.0 mGy. The dose ratios between adults and 1-year-old infants were similar to those obtained for evacuated residents. According to the calculations, in general, in the whole of Fukushima Prefecture (population about 2 million people) a few hundred infants have been estimated to have received absorbed doses to the thyroid of more than $100 \mathrm{mGy}$.

The document notes that the UNSCEAR 2013 reported dose estimates of workers involved in mitigation at the Fukushima Daiichi Nuclear Power Station site remain generally valid. The average effective dose of the 21,135 workers from March 2011 to the end of March 2012 was about 13 mSv. About $36 \%$ of the workforce received total effective doses of more than $10 \mathrm{mSv}$ over that period, while $0.8 \%$ received doses of more than $100 \mathrm{mSv}$. The new document revised the individual dose estimates for six workers with effective doses over $250 \mathrm{mSv}$. As a result of individual measurements of thyroid size for the six workers and taking these data into account in the dose estimates, the calculated values of the absorbed thyroid dose increased for five of them, and declined for one person. For one of the workers, the thyroid exposure dose increased by almost a factor of three. The maximum value of the thyroid dose of workers due to the inhaled radioiodine is estimated as 32 Gy.

The UNSCEAR 2013 report documented no adverse health effects among Fukushima residents that could be directly attributed to radiation exposure from the Fukushima Daiichi Nuclear Power Station accident. The updated estimates of doses to members of the public have either decreased or are comparable with the Committee's previous estimates. The Committee therefore continues to consider that future health effects directly related to radiation exposure are unlikely to be discernible from pre-existing diseases. The document stresses that although a large number of thyroid cancers have been detected among the Fukushima Prefecture residents exposed in childhood, increase in the number of thyroid cancers results not from radiation exposure, but rather from ultrasensitive thyroid screening procedures.

Despite the fact that red bone marrow dose estimates in the population did not increase, estimates of leukemia risk per mGy increased somewhat compared to the UNSCEAR 2013 estimates. However, the application of risk models based on the experience of analyzing the consequences of the atomic bombing of Hiroshima and Nagasaki, any cases of an increase in the number of cases of leukemia with the obtained estimates of exposure doses to red bone marrow after the Fukushima 
accident are unlikely to be reliably identified in any age group of the population. However, at such low doses of red bone marrow exposure statistically significant increase of the leukemia risk in population is hardly to be observed in the future either. Likewise, the levels of public exposure have been too low to expect discernible increases in the incidence of breast cancer or other solid cancers.

With regard to the exposure of clean-up workers, it was also noted that since most workers received low exposure doses (effective doses for the first year are less than $10 \mathrm{mSv}$ ), it is unlikely that an increase in the incidence of leukemia, solid cancers, including thyroid cancer, will be reliably detected in clean-up workers. The report points out that the information is rather limited to make a reliable judgment about the risk of cataract.

In the section "Radiation exposures and effects on nonhuman biota" it is stated that regional impacts on wildlife populations would have been unlikely although detrimental effects on individual organisms might have been possible. A few scientific publications have indicated various cytogenetic, physiological and morphological (sublethal) effects in some plants and animals that have been observed in areas of increased radiation levels following the Fukushima accident in the absence of any reported wide-scale group impacts. In contrast, substantial population- and ecosystem-level impacts on selected wildlife groups were observed in areas of increased radiation level due to fallout following the Chernobyl accident.

An obvious drawback of this section is the use of criteria that exclude the effects of chronic low-dose exposure of biota. This is primarily due to gaps in the recommendations of the International Commission on Radiological Protection (ICRP) regarding biota protection. It was noted that many of the effects in plants and animals described in publications were incorrectly associated with exposure after the Fukushima Daiichi Nuclear Power Station accident, and the obtained data need to be reassessed. It should also be noted that the follow up period after the Fukushima Daiichi Nuclear Power Station accident is insufficient to detect many population effects in biota, such as radioadaptation or effects associated with radiation-induced genome instability. It explains the necessity to conduct further studies in the near zone of the Fukushima Daiichi Nuclear Power Station, taking into account the experience gained in similar Chernobyl studies.

Document R.743 "Biological mechanisms relevant for the inference of cancer risks from low-dose and low dose rate radiation»

The expert group chaired by Simon Bouffler have done great job on preparing the final document. The experts were able to compile in a document sufficient data on the low-dose and low dose rate effects that could be involved in carcinogenesis. The document comprises mainly the new data obtained over the last 10 years. The presented results of the studies are well arranged in accordance with the levels of organization of living systems. The focus in the document is made on the response of the cells, including the stem cells, to low doses: DNA damage, damage of signaling pathways, epigenetic changes, chromatin remodeling, changes in the gene and protein expression. DNA reparation, adaptive response and non-targeted effects have been considered. Some attention has been paid to the lowdose effect on non-nucleated cellular components.

Despite great job done it is clear that nowadays it is still not possible to form a systemic view of cancer mechanisms following exposure at low doses. The authors centered on the cellular response to low doses. However, the reactions of tissues, organs and body as a whole practically were not considered. No data are presented on the status of the local anti-tumor immunity which has a profound impact on the tumor progression. The low-dose effect on the endocrine system which contributes to the induction of such hormonedependent cancers as breast cancer has not been given any consideration.

Another issue which has not been covered by the report concerns the specificity of carcinogenic mechanisms of the low doses. This issue is rather complicated and requires thorough analysis. The authors declared in the document that they examined only the role of dose-dependent effects in carcinogenesis, i.e. of the effects that from their point of view are radiation-induced. Such approach seems dubious for a number of reasons. First of all, dose dependence is most often registered for the effects of high doses. Moreover, lowdose effect and especially of functional responses of the cells (for example, changes in the gene expression and apoptosis) is characterized by triggering mechanism. That is why the analysis of the carcinogenesis mechanism at low doses based only on the dose dependent effects does not seem justified.

The weakest part of the document is the analysis. It is obvious that with the accumulation of the new facts on the low-dose effects it is necessary to analyze them. In this regard, it would be important to analyze whether the newly revealed effects of low doses that from the point of view of the authors are relevant to the carcinogenic mechanisms conform to the present day radiobiological and oncological concepts and theories of the carcinogenesis.

Unfortunately, such issue as radioadaptation (in published scientific papers it is also known as radiation adaptive protection) which is crucial for the understanding of the mechanism of low doses was not touched upon in the document. Today it is evident that without understanding of this phenomenon it is basically impossible to understand the mechanisms of biological effects of low doses. The document discusses the radioadaptive response of the cells. However the mechanisms of the adaptation of tissues, organs, and body as a whole were not considered. Even though the document has one section devoted to the mechanistic models of cancer, which addresses initial and very limited processes of malignant transformation of a cell following the exposure, but apparently it is not enough.

Nevertheless, despite the noted weak points of the Report which are objective and are connected to the shortage of such data, the document could be viewed as the basis for future studies. It should be stated that today it is impossible to develop a comprehensive view of the cancer mechanisms following the low-dose and low dose rate exposure. Taking into account the fact that the report uses a lot of special terminology and abbreviations that are accepted in immunology, molecular genetics and other fields of studies it is important to recommend to make a list of abbreviations and terms. In general the document should be regarded as very important for the future work of the Committee.

\section{Document R.744. "Evaluation of occupational exposure to ionizing radiation»}

Since 1977, UNSCEAR has been publishing reports on the assessment of occupational exposure levels. Estimates presented in the given document are based on data obtained from UN Member States over the period from 2010 through 2014, supplemented by information published in national reports and open sources. The principal objective of the report 
is to assess the exposure of workers of various professional groups from sources of ionizing radiation based on the criterion of the average annual effective exposure dose.

To achieve the set goal, it was intended:

- to estimate the worldwide level of occupational exposure within various professional sectors;

- to identify new groups of workers receiving high doses of radiation in connection to the introduction of new technologies using radiation sources;

- to assess the impact of changes in regulatory standards or requirements on the tendency of dose formation.

Unlike previous reports, much attention is paid to the effects of natural sources of ionizing radiation. The document presents the analysis of the information on four sectors related to the impact of natural radiation sources on:

- aircrew and space crew;

- workers in mining and processing industry;

- workers engaged in gas and oil extraction industries;

- radon exposure in workplaces other than mines.

Data on occupational exposure to man-made sources of radiation include:

- nuclear fuel cycle;

- medical use of radiation (including veterinary medicine);

- industrial use of radiation;

- various groups of workers not included in the sectors described previously, including educational establishments; management of radiation sources used in industry, science and medicine; transport of radiation sources and radioactive materials. It also includes an assessment of the impact of manmade radiation sources when used for military purposes.

The approach used by the expert group was to provide a basic rationale for the methodology for estimating doses of cosmic ray exposure, external and internal exposure doses, radon exposure doses and doses to the lens of the eyes, based on the recommendations of the International Commission on Radiation Units and Measurements (ICRU) and ICRP.

Criteria for selecting the workers to be monitored and exposure to be recorded differ considerably between countries. Some countries monitor only exposed workers, while others include non-exposed workers in their individual monitoring programs for various reasons. Moreover, exposure due to radon is often underestimated, as in many countries the exposure dose is registered only if the concentration of radon in the air exceeds $1,000 \mathrm{~Bq} / \mathrm{m} 3$ in the workplace.

As it has been mentioned, four groups of countries are distinguished based on the income level: low income, lowermiddle, upper-middle and high income. At the present stage of data collection, it seems possible to assess trends in personnel exposure only for countries with a high level of economic development. Attempts by the working group to extrapolate the resulting methodology to low- and middle-income countries were unsuccessful. First of all, this can be explained by the low efficiency of collecting data on occupational exposure in these countries.

By the end of 2020, it is planned to complete work on the assessment of exposure levels during the reprocessing of spent nuclear fuel, oil and gas extraction, and in veterinary medicine. The report is scheduled to be published in 2021. The UNSCEAR Secretariat expressed gratitude to international organizations for their contribution to the preparation of the report.

Document R.745 «Second primary cancer after radiotherapy»

The project was approved by the Committee for inclusion in the program of work at the 65th session of UNSCEAR. At the $66^{\text {th }}$ session, the document was designated a "high priority" document and a group of experts was established to prepare it. At the $67^{\text {th }}$ session of UNSCEAR, a group of experts presented to the Committee a progress report and a clear work plan with specific timelines.

The presented report includes a detailed description of the principles of literature search by agreed and approved keywords; selection criteria for literary sources; structure of tables to describe the results of studies of individual organ-specific cancers and meta-analyses performed to refine risk estimates; as well as the full content of the report. From the point of view of the experts, the document should contain the following main sections:

- dosimetry, including an overview of dosimetry quantities, calculation of exposure doses in various treatment protocols; dose reconstruction using physical and computational phantoms, detectors and dosimeters; methods for measuring and calculating the uncertainty of exposure doses;

- radiobiology, including the description of the molecular mechanisms of radiation-induced cancer development, assessment of the contribution of other factors (sex, age, lifestyle, environmental factors, etc.); the role of the microenvironment in the development of second cancer; mathematical models allowing to predict radiotherapy induced cancer risk; biological dosimetry;

- oncology, including definitions and diagnostic criteria for second primary cancers after radiotherapy; description of genetic tests; type and incidence of certain second cancers (breast cancer, lung cancer, malignant neoplasms of lymphoid and hematopoietic tissue, sarcoma, thyroid cancer, brain cancer, etc.); prognosis and prevention of second cancers after radiotherapy;

- epidemiology, including the literature review of data on the incidence and lifetime risk of second primary cancers following radiotherapy, including for the selected cancer sites listed above; risk prediction models; comparison of second primary cancer risk from radiotherapy to cancer risk from other radiation exposures; limitations of existing evidence of risk, major uncertainties and gaps in knowledge;

- conclusion and recommendations.

The Committee unanimously endorsed the work done, emphasizing the urgency and importance of this problem for society in connection with the increase in the number of diagnostic methods and therapy using sources of ionizing radiation and the increase in life expectancy after treatment of the first cancer.

When discussing further work plans, the Committee recommended that the experts in a future report: a) present clear criteria for the differential diagnosis of second cancers following radiotherapy and metastatic neoplasms; b) consider issues related to individual radiosensitivity; c) clarify the effect of additional types of treatment (chemotherapy, hormone therapy, etc.) on the risk of second cancer development; d) evaluate the impact of diagnostic methods (CT, nuclear magnetic resonance imaging, etc.) on the risk of second cancer development following radiotherapy.

\section{Document R.746 «Epidemiological studies of radiation and cancer»}

Currently, the Committee is carrying out another project devoted to the study of the relationship between radiation and cancer, which testifies to the urgency of this problem. Over the 75 years after the atomic bombing of Hiroshima and Nagasaki, as a result of the rapid development of atomic power engineering and extensive use of radiation sources, considerable amount of scientific data has been accumulated 
on the consequences of radiation exposure to human health as a result of radiological emergencies, occupational and medical exposure, as well as exposure as a result of radioactive contamination of the environment. The aim of the project is to publish a comprehensive scientific review prepared using the evidence obtained after the release of the UNSCEAR 2006 report (Annex A. Epidemiological studies of radiation and cancer). Risk estimates from the study of the Japanese cohort have not changed appreciably over the last several decades, and there has been minimal change in estimates of radiation detriment. However, updated data are important and necessary. During the 66th session in 2019, a decision has been made to analyze epidemiological studies conducted in various research centers. Out of several thousand scientific papers 561 relevant articles have been selected to be used in preparation of the evidence-based scientific review in accordance with the quality criteria of scientific epidemiological studies provided in Annex A to the UNSCEAR Report 2017. The screening criterion was the research question, the answers to which could be found in the articles. This research question was formulated as PECO statement (Populations, Exposures, Comparators, and Outcomes) used in the evidence based medicine. Results of the studies should fit this statement. Research questions related to the effect of low doses or low-LET radiation on cancer development, excess risk dependence on the cancer site; the effect of exposure dose rate, sex, age at exposure and time elapsed after the exposure, on excess risk value. It is also necessary to assess the risks of developing cancer of various localizations when exposed to low doses or low dose rates, and to carry out the uncertainty analysis. Moreover, it is essential to evaluate quality, reliability of information sources, the feasibility and ways of updating the 2006 report by combining it with new data.

New information obtained as a result of the study is important for the preparation of recommendations on radiation protection, the forecast of radiation risks caused by the use of radiation in various fields of human activity.

\section{Document R.747. "Evaluation of public exposure to ionizing} radiation from natural and man-made sources»

The study of the effects of natural and man-made sources of ionizing radiation (IRS) on the population has been the subject of constant attention of UNSCEAR since 1955, which resulted in a number of publications of the Committee. The latest document on this issue was published in 2008, and there is a need to update it. In 2019, at the 66th session of UNSCEAR, the decision has been made to prepare an updated report. For this purpose, an expert group consisting of experts from 17 member states (including Russia) and observers from four international organizations (European Commission, IAEA, NEA OECD and $\mathrm{WHO}$ ) was established. The updated report is scheduled for publication in 2024.

The aim of the project is to provide a comprehensive and independent assessment of the effect of all major sources of public exposure. The main objectives of the project are to analyze and update, if necessary, the methodology of radiation dose assessment, assess the variability and uncertainty of public exposure, identify temporal trends in exposure, geographic patterns and environmental features in public exposure worldwide. There will be established working groups in the following areas of public exposure: 1) natural radiation sources; 2) radon exposure; 3) nuclear fuel cycle (nuclear power production); 4) nuclear fuel cycle (spent fuel and radioactive waste management); 5) other applications of radioactive materials; 6) past military use of IRS and nuclear legacy sites; 7) residential areas contaminated as a result of past nuclear and radiological accidents and other incidents. A separate group of experts has also been established to assess the quality of incoming information, including the assessment of data uncertainties and exposure doses to the population. Information for analysis will be collected from two main sources: review of literature data for the period from 2007 to 2022 and data obtained from UN member states in the form of completed questionnaires in all areas of the expert group's work. Questionnaires have been prepared to collect information in this format. It is planned that completed survey forms will be submitted via the National Contact Persons nominated by the UN Member States to carry out the work on this project.

Document UNSCEAR/67/7 «Implementation of the Committee's strategy to improve collection, analysis and dissemination of data on radiation exposure»

The project to collect data on radiation exposure of personnel and the public is a long-term strategic task that the Committee implements in three areas: analysis of data provided in peerreviewed scientific literature, interaction with international organizations (WHO, ILO, IAEA, etc.), collection of data from UN member-states in the form of national questionnaires. The information collected by the Committee serve as the scientific underpinning of UNSCEAR documents on occupational and public exposure from sources of ionizing radiation. In 2019, an ad-hoc working group was established to optimize the collection and analysis of data from UN member states and stratify global estimates of radiation doses for the world's population. As part of the group's activities, interactions with national contact persons were arranged in a form of a survey to understand the difficulties or challenges in data collection and submission. The results of the conducted study showed that the main problem is related to the fact that the systems for collecting data on public exposure existing in the countries do not allow providing the information requested by UNSCEAR in full. Therefore, the main sources of data for the preparation of UNSCEAR reports at the moment are still scientific publications and databases of international organizations. And here there is a number of problems. In some cases, the data collected from the scientific publications are not representative. For example, when assessing environmental contamination levels, there are significantly more data provided by areas with high background levels of exposure. This imbalance in data needs to be thoroughly investigated, especially in case of public exposure assessment. Similarly, whereas there are sufficient data on external exposure, there is notably less information on internal exposure of the population. One of the important questions is how to ensure consistency in the estimates of population exposure, for example, in terms of the effective dose. Experience has shown that countries often use different values of tissue coefficients when assessing population exposure doses, which could be difficult to determine when analyzing exposure doses. In the opinion of the working group, this issue should be addressed in a survey manual or glossary explaining the methodology used to measure, calculate or report effective dose. In 2020, work on collection of data on natural and manmade exposure of the population was started. For this project, the Committee recommended the appointment of National Contact Points (NCPs) from UN Member States. To effectively carry out this activity, the working group recommends improving the interactive format of the UNSCEAR online platform as a tool for submitting information to the NCL, optimizing cooperation 
with international organizations and other institutions for the completeness of data collection in this area. It should be emphasized that in view of the fast technical development in the medical field, the working group recommends starting the collection of new data on medical exposure of the population already in 2024.

\section{Scientific communication and public relations - a new area of UNSCEAR activities}

In 2021, UNSCEAR will celebrate the $65^{\text {th }}$ anniversary from the date of its foundation. The tasks assigned to the Committee in the late 1950s included a comprehensive assessment of the levels and effects of atomic radiation and the preparation of reports so that governments and international organizations could rely on them when making decisions in the field of radiation protection, regulation and other matters related to the ionizing radiation effect. For 60 years, UNSCEAR has regularly issued scientific reports and reviews, on the basis of which the ICRP and the IAEA prepared their publications and recommendations. In the professional environment, the authority of UNSCEAR is extremely high, the UN General Assembly invariably appreciates its work and emphasizes the importance of the tasks it solves, including the assessment of the consequences of severe radiation accidents [1]. However, over the past decade, UNSCEAR has been experiencing serious funding problems and a lack of staff.

Recognizing that in present-day conditions the solution of these problems hinges on the success of scientific communication and public relations, in 2014 the UNSCEAR Secretariat developed an outreach strategy for the next decade (document UNSCEAR/67/8). The goal was defined as follows: to deepen the understanding of the levels and effects of radiation among all stakeholders, not only researchers and scientists, but also decision-makers, their advisers, the scientific community, students and journalists. New target audiences include decision makers and their advisers, academia, students and journalists. In the context of a limited budget and top priority of scientific work, traditional tools of scientific communication were chosen - a public website, topic-specific information materials and news releases for the media, contacts with governments and international organizations, etc. In addition, the Secretariat planned to prepare for the 10th anniversary Fukushima accident an updated version of Appendix A to the 2013 UNSCEAR report

The results of the work performed in 2014-2019 and plans for the future were presented for discussion at the $67^{\text {th }}$ session. They did not cause much discussion. The suggestion of Abel Gonzalez, who is wise from experience in scientific communication, to focus on preparing a popular brochure on Fukushima, which should become a hit for the general scientific community like the well-known 1985 brochure "Radiation. Doses and Effects"[2] for the 10th anniversary, did not receive support due to the forced postponement of the preparation of the updated Annex A to the UNSCEAR 2013 report. The Secretariat's report was approved, the work plan and the request for additional funding for communication activities in 2020-2024 were endorsed.

Nevertheless, not everything is as good as it may seem. For most of the participants in the session, as well as for the members of the Secretariat, the very notion of scientific communication is far from their purely scientific interests. If we analyze UNSCEAR's attempts to move in a new direction from the standpoint of the experience accumulated by the IAEA, ICRP, WHO and other international and national expert organizations in the field of communication of scientific knowledge on health risks, the conclusion is not comforting.

To begin with, the UNSCEAR communication strategy aims to deepen the understanding of scientific information outside the professional community. In fact, there is nothing to deepen in this area - public perceptions are very far from scientific knowledge. All target groups with whom UNSCEAR is going to work, as well as society as a whole, are convinced that serious damage to health from radiation is inevitable, regardless of the dose, and that medical consequences of Chernobyl and Fukushima accidents were disastrous. For example, in Russia, the gap between respondents' assessments and scientific data on the number of deaths from radiation exposure as a result of these accidents reaches 3-4 orders of magnitude. Moreover, the distribution of respondents' answers basically does not depend on age, education, social status and place of residence of the respondents [3]. There is reason to believe that the situation is similar in other countries. We see that the gap between public opinion and scientific knowledge does not decrease over time, traditional approaches to scientific communication are not effective. One of the main barriers is the disagreement in the professional environment regarding the scientific validity and expediency of using the linear non-threshold hypothesis in the range of fundamental scientific uncertainty, but the professionals themselves still clearly underestimate the importance and influence of their consolidated opinion on the public perception of risk

The preservation of the "status quo", as we can see from the example of the UNSCEAR, is already beginning to threaten with a decrease in the financial stability of scientific activity. The reasoning is simple: if over 65 years scientists have not been able to answer the question how serious the risk for mankind from additional man-made exposure is relative to the natural background, then is it worth continuing to divert financial resources to continue this work when more pressing problems are on the agenda, the solution of which is required here and now. Not surprisingly, the Governing Council of the United Nations Environmental Program (UNEP), consisting of representatives from 58 countries, is no longer reallocating resources in favor of UNSCEAR. In this situation, apparently, the main thing for the expert community is not to stand still, to break the internal inertia, to recognize new challenges, since a well-formulated problem is a half-solved problem.

\section{Conclusion}

The $67^{\text {th }}$ session of UNSCEAR took place as an online meeting from 2 to 6 November 2020. During the Session the Scientific Committee discussed 7 Scientific Reports, Future Programme of Work of the Committee (2020-2024), Implementation of public information and outreach strategy, Report to the General Assembly, and organizational aspects of the Committee's activities. Based on the results of the discussion decision has been made to finalize and publish the following documents in 2020: R.741 «Evaluation of medical exposure to ionizing radiation»; R.742 «Levels and effects of radiation exposure due to the accident at the Fukushima Daiichi nuclear power station: implications of information published since the 2013 UNSCEAR report»; R.743 «Biological mechanisms relevant for the inference of cancer risks from low-dose and low dose rate radiation»; The Comittee planned R.744 «Evaluation of occupational exposure to ionizing radiation for publication in 2021».

The Committee decided to extend the mandate of the adhoc working group on the effects of radiation exposure and the 
biological mechanisms by which they occur for one year, and established the second ad-hoc working group on sources and exposure of the population. The next session of UNSCEAR is planned to take place from 21 to 25 June 2021.

\section{References}

1. Resolution adopted by the General Assembly on 13 December 2019. A/RES/74/81. UN General Assemble. 26 December 2019. Avialable from: https://www.unscear. org/docs/GAreports/2019/A_RES_74_81_E.pdf (ref. date 19.11.2020).

2. Radiacija. Dozy, jeffekty, risk. Per. s angl. M.: Mir, 1990; 79 s.

\section{Литература}

1. Resolution adopted by the General Assembly on 13 December 2019. A/RES/74/81. UN General Assemble. 26 December 2019. Available from: https://www.unscear.org/docs/GAreports/2019/A RES_74_81_E.pdf (дата обращения 19.11.2020).

2. Радиация. Дозы, эффекты, риск. Пер. с англ. М.: Мир, 1990; 79 с. Доступно по ссылке: http://cdn.sbor.ru/Files/

Avalable from: http://cdn.sbor.ru/Files/file/02_radiatsiya_dozu, effektu,_risk.pdf (ref.date 20.11.2020)/.

3. Melikhova EM, Byrkina EM, Pershina YA. On the issue of certain mechanisms of social amplification of risk in media coverage of the Fukushima NPP nuclear accident. Medical Radiology and Radiation Safety. 2013; 58 (4): 5-16. Russian.

file/02_radiatsiya_dozu,_effektu,_risk.pdf (дата обращения 20.11.2020)

3. Мелихова Е. М., Быркина Е. М., Першина Ю. А. О некоторых механизмах социального усиления риска для здоровья при освещении в СМИ аварии на АЭС Фукусима. Медицинская радиология и радиационная безопасность. 2013; 58 (4): 5-16. 